\title{
The Tensioned Nature of Curriculum Reform: What the Kingdom of Saudi Arabia Can Learn from the Experience of Others?
}

\author{
Brendan Mitchell
}

Abdulrahman Alfuraih

\author{
Doi:10.5901/jesr.2016.v6n3p93
}

\section{Abstract}

\begin{abstract}
This paper examines the tensioned nature of curriculum intent and reform or re-energization with a particular focus on English language teaching and learning. The paper presents recent examples of referenced examples of English language curriculum reform projects in South Korea, Malaysia, Indonesia and the Gulf Cooperation Council Countries which the Kingdom of Saudi Arabia can draw upon in its continued and imperative education reform initiatives. In addition to discussing the (English language) curriculum reform efforts of the aforementioned countries and region the tensions associated with the reforms are investigated and reported. The paper highlights the critical relationship between both professional development for teachers and school leadership support and curriculum reform which are the variables to achieving curriculum reform success. Successful curriculum reform is necessary for the Kingdom of Saudi Arabia (and Arab nations in general) to recognize economic and development goals and move away from an economy solely reliant on oil revenues.
\end{abstract}

Keywords: Curriculum, tension, English language, teaching, development

\section{Introduction}

This paper presents recent examples of referenced events that are used to demonstrate the tensions that exist in curriculum intent and reform or re-energization with a particular focus on English language teaching and learning. The paper highlights examples of conflicting national imperatives, especially, in religion and economics, come to the foreground in the decision-making level around curriculum priorities. This inherent reference to tensions is evident in Pinar, W. F., Reynolds, W. M., Slattery, P., \& Taubman (1995) who state:

(Curriculum) is what the older generation chooses to tell the younger generation..(it) is intensely historical, political, racial, gendered, phenomenological, autobiographical, aesthetic, theological and international. It becomes the site on which the generations struggle to define themselves and the world (p.847-848).

This comment provides a foundation for understanding the tensioned environment of curriculum design, development and implementation because at each level of the process, those involved, even teachers at the classroom level, seek to see manifest their own imperatives for education (Pinar et al, 1995). From a historical standpoint, Al-Farabi was the leading philosopher in what is now the Middle- East during the tenth century, and whose works were recognized in both the East and West. "Al-Farabi's view on education can be summed up as, the acquisition of values, knowledge and practical skills by the individual, within a particular period and a particular culture" (Al-Talbi, 1993, p.2). Al-Farabi goes onto say, "The goal of education is to lead the individual to perfection since the human being was created for this purpose, and the goal of humanity's existence in this world is to attain happiness, which is the highest perfection-the absolute good" (Al-Talbi, 1993, p.2). It also demonstrated Al-Farabi's contribution to understanding both traditional and contemporary educational philosophies and the tensions associated with tradition, especially the religious foundations of Islam and the contemporary economic aspirations for a nation. These contributions are significant because they continue to influence curriculum development today. More recently, documentation from both the Ministry of Economy and Planning National Development and the Ministry of Education have included commitment and support for curriculum reform and development in the Kingdom of Saudi Arabia. It is noteworthy that beyond these documents and Al-Farabi's contribution, there is not widely available literature on education and curriculum reform in Saudi Arabia; particularly historical literature. Consequently, to develop a better understanding of the tensions in curriculum, especially English language curriculum, the paper includes not only literature on education and curriculum reform in Middle Eastern and Islamic countries but also other countries, where relevant. The emphasis is to demonstrate the tensioned nature of 
curriculum.

The paper provides a brief but original contribution to current curriculum reform efforts in the Kingdom of Saudi Arabia which is an area lacking in current published research. It is foundation paper. As curriculum and associated reform activities progress the paper will provide a reference point for further in depth studies on both reform activity development and its successes.

\section{Methodology}

The methodology followed was a literature review which included an analysis of the selected references, an analytical qualitative research method for reviewing and evaluating documents (Bowen, 2009). The content analysis was directed by Braun and Clarke's (2006) six phase process was used for the analysis: familiarization with the (categorized) data set; generating initial data; searching for themes; checking identified themes; refining themes; and reporting on these findings. This six-step process is evident in the discussion to follow.

The methodology followed enabled the primary question of this paper, "The Tensioned Nature of Curriculum Reform: What the Kingdom of Saudi Arabia Can Learn from the Experience of Others?" to be explored and highlighted in the conclusion that while models of other countries could be followed there will be significant tensions associated with the reform efforts. The documents selected are current and relevant to reform efforts in the Kingdom of Saudi Arabia and what the Kingdom can learn from the experience of other nations and their reform efforts.

\section{The Asian Experience}

Not all the countries discussed in this section are predominantly Muslim. Those that are included seek to illustrate the tensions around curriculum as a "site on which the generations seek to define themselves" (Pinar et al., 1995, pp. 847848).

South Korea is a developed and economic powerhouse which was severely affected by the 1997-1998 Asian financial crises. The Asian financial crisis "was the catalyst for a set of socioeconomic transformations that led to the imposition of competitiveness as a core value for a nation" (Lee, 2012, p.1). In South Korea, English language competency is seen as a sign of competiveness and some of the curriculum and instruction reforms that have taken place are the vertical and horizontal integration of English into other subject areas and certain universities introducing English as the medium of instruction. Complementing these reforms has been the continued growth in English language training centers and having English language speakers in government schools. As has been noted the Asian financial crisis was an agent for change in South Korea. However, curriculum reform in South Korea has not occurred without controversy, especially with the attention given to the educational pressures students are under which have been attributed to rising levels of suicide (Lee, 2012). This can be seen to be an example of how "curriculum is what the older generation chooses to tell the younger generation" (Pinar et al. (1995, p. 847-848), which, in turn, places undue pressure on students to perform.

Malaysia is another Asian country where economic imperatives have strongly influenced curriculum reform. The term 'Asian Economic Tiger' was used to describe it prior to the Asian financial crisis (Lee, 2012). Malaysia has undergone numerous English language curriculum reforms since obtaining independence from the United Kingdom in 1957 (White, 2004), including the priority placed on English as the language of instruction in all subject areas. What can be described as ongoing curriculum change processes in Malaysia, which privilege English language inclusion, have not occurred without disagreement, especially with attention to debates around nationalism and sovereignty and the desire to distance themselves from their former colonial masters (Selvaraj, 2010).

This tension to include English is evident in a variety of developments. For example, Selvaraj (2010) quotes the then Malay Prime Minister Datuk Seri Dr. Mahathir Mohamad who said in 1991, "that Malaysia might lose its economic competitiveness and find it hard to progress in the industrial and technical fields" (p. 52) if Malaysia decides to change from English as the language of curriculum instruction. This has resulted in not only curriculum reform but also language policy changes in Malaysia.

Curriculum reform in Malaysia can be seen to fall under Eisner's (1985) social adaptation and social reconstruction orientation to curriculum, where the function of curriculum is two-fold - to develop manpower for a nation and, secondly, to create good citizens. Kabilan (2007) recognizes Malaysian students in remote and rural areas are not provided with the same level of instruction, especially in English language exposure, as students in urban areas which likely hinders the intent of the reform efforts. Kabilan (2007) goes on to recognize, "the emphases on English as an academic subject 
and a tool for economic attainment" (p. 681). So while curriculum reform can be seen as a tool for economic development, not all students are allowed to access this capital that is identified as central to participation in the economic imperatives.

The world's largest Muslim country, Indonesia, has been undergoing curriculum reform in recent decades. Before discussing the curriculum in Indonesia it is important to note that two different government ministries oversee education in the huge archipelago, the Ministry of Religious Affairs (which is responsible for the Islamic schools) and the Ministry of National Education. A 2013 curriculum reform initiative in Indonesia has seen the piloting of a new curriculum in 6000 schools. It "instantly drew controversy after it removed science, English, social sciences, and information technology (IT) as separate subjects in favor of Bahasa Indonesian, nationalism and religious studies" (Palatino, 2013, para. 1). Whilst the decrease in the number of subjects students undertake at both primary and junior high school might be seen as a positive by the Ministry of National Affairs and citizens calling for a more substantive religious base to schooling, the deprioritization of core subjects is inconsistent with developing labor market skills and modernizing an economy (Palatino, 2013). These reforms are at odds with most developments in Asian and Middle East countries, such as the Kingdom of Saudi Arabia where emphasis of the curriculum reform efforts is on STEM (science, technology, engineering and mathematics) and English. These subjects are seen as essential for future economic prosperity. Additionally, extracurricular activities, community participation projects, Arabic language, school leadership, technology, professional learning communities, partnerships and professionalizing the teaching profession are initiatives contributing to the overall improvement of teaching and learning in the Kingdom of Saudi Arabia. Investing in human capital through education is seen as a central mandate for the improvement in the quality of education as the continuation of the investment in future generations in order to transform the Kingdom into a knowledge based society.

There is no literature available, as yet, elaborating on the outcomes of the 6000 school curriculum pilot project in Indonesia. Informal feedback from teachers indicates dissatisfaction with this imperative, and the in-service training provided to teachers has been insufficient (Palatino, 2013). This is a key point Kabilan (2007) discussed in relation to the Malaysian context where teachers knowledge and pedagogical approaches influence the success of a curriculum and in essence the received curriculum.

I have stated previously that the curriculum reform efforts in Indonesia are in contradiction to developments occurring elsewhere. A prime reason for this is because of the growth of schools, especially independent schools, offering Cambridge qualifications in Indonesia (Cambridge International Examinations, 2015) which includes the "National Plus schools which are government schools that teach an international curriculum alongside the local standard Education Department curriculum" (Ferras, 2012, para. 3). As of April 2014, there is a Cambridge IGCSE Bahasa Indonesia qualification for students. So on one hand while the pilot program for 6000 schools is increasing religious education at the expense of other core subjects, government schools are embracing and adopting international curriculum and practices. This polarity in intent between state and independent schools will undoubtedly contribute to, or at least perpetuate, ongoing tensions around the contested space of curriculum in Indonesia.

\section{The Gulf Cooperation Council Countries}

Closer to the Kingdom of Saudi Arabia, the Gulf Cooperation Council Countries, which in addition to the Kingdom of Saudi Arabia is made up of the United Arab Emirates, Kuwait, the Kingdom of Bahrain, Qatar and the Sultanate of Oman, are undergoing curriculum reform. The Gulf Cooperation Council Countries share a common outlook with regard to religion and its practices, although with some slightly different interpretations and laws. The council member countries share similar histories and beginnings, cultural, language and socio-political domains.

Education reform in the six member countries is seen as a key in driving the countries forward. One of the few people who have written and published extensively on education reform in the region is Al-Issa (2012) who says:

In their pursuit of development, advancement and modernization, all of the six oil producing and rich GCCC recently started to restructure and reform their education systems in terms of quality and quantity in order to respond to the world technological, social, economic and political changes, challenges and demands, which mold and steer the needs of the individuals, who make the prime resource of development in any country (p. 538).

Maroun et al. (2008), while discussing how to succeed at education reform in the Kingdom of Saudi Arabia and the Gulf Cooperation Council Countries, talk about the links to economic development and the links to the socioeconomic environment which was a key motivator in education reform in South Korea (Lee, 2012). Maroun et al. (2008) go onto say: 
The urgency for education reform in the Arab world has been manifested in the various initiatives aimed at improving the quality and quantity of education, especially with a rising young population that represents a majority in many countries of the Arab world. Recent years have witnessed many Arab countries making efforts to develop and implement comprehensive education reform programs that can result in a skilled, knowledge-based workforce in line with socioeconomic goals (p. 1).

English language teaching curriculum reform is deemed as a key component in curriculum reform due to it being a world language and essential for trade and enterprise in the world of globalization. The importance of English language teaching is evident in the Kingdom of Saudi Arabia with recent reforms to the English language curriculum and accompanying instruction being implemented. However, the outputs from these changes will take a number of years to be realized as is evidenced by the poor English language proficiency of current graduates (Arab News, 2014a). This identified deficiency has long been recognized as an impediment to seeing an educational goal. For example, Richards (2010) notes that most of the regions English language teachers are non-native speakers of English. In the Ministry of Education K-12 schools in the Kingdom of Saudi Arabia English teachers are typically Saudi nationals. This is different from some of the other countries previously discussed such as South Korea, Malaysia and other Gulf Cooperation Council Countries, which have a blend of expatriate teachers within their public school systems. The situation in the Kingdom of Saudi Arabia brings with it potential tensions. First, in referring to the needs of non-native speakers of English, Richards (2010) states, "there is a threshold proficiency level the teacher needs to have reached in the target language in order to be able to teach effectively in English" (p. 103). Unfortunately Richards (2010) does not align this statement to a quantifiable International English Language Testing System (IELTS) or Test of English as a Foreign Language (TOEFL) score. To put this in perspective both internationally and within the Saudi Arabian context, non-native speakers of English who would like to enter an undergraduate pre-service teacher education program in an Anglophone country typically require an academic IELTS score of 7.0 or above across all four bands. In the Kingdom of Saudi Arabia, while there is no official English language proficiency requirement for English language teachers a discussed target for English language teachers is academic IETLS 6.0 or TOEFL iBT 71.

Khan $(2011 \mathrm{a}, \mathrm{b})$ acknowledges that there exists a poor level of English language teaching education in the Kingdom of Saudi Arabia. Al-Issa (2011) notes that this is common throughout the Gulf Council Cooperation Countries. Both Khan (2011a, b) and Al-Issa (2011) recognize and stress the importance of providing professional development for English teachers, which is an essential element for a positive impact on learners' language improvement. In essence, teacher up-skilling programs provide the crucial element in determining the success of the (new) curriculum through improved instruction.

Secondly, it is quite possible that some (English) teachers do not subscribe to the national curriculum imperatives. It is possible they do not see, as Fullan and Miles (1992) suggest, the 'worthwhileness' of such initiatives and may consciously or unconsciously resist such efforts because of their belief systems (Allam, 2011). Saudi Arabia is fundamentally a conservative country and initiatives that draw into question fundamental conservative foundations are likely to be contested by those charged ultimately with the imperative of enacting curriculum.

\section{Interdependence Between Curriculum Reform and Teachers' Skill}

The interdependence between curriculum reform (and its success) and teachers' skill has been discussed in relation to the Indonesian and Malaysian contexts. Wiseman and Al-bakr (2013) are one of the other few researchers who have published a range of literature on education reform in the Middle East, and, in particular, in the Gulf Cooperation Council Countries. Wiseman and Al-bakr (2013) discuss how the Gulf Cooperation Council Countries have teacher competence high on their agenda in curriculum reform implementation. Policy makers have linked (low) student performance to placing a focus on teacher quality and teacher improvement and the introduction of teacher standards to improve teachers' standards.

While there are numerous initiatives around teacher development and improvement to support curriculum reform in the Kingdom of Saudi Arabia there are also a range of inhibitors. When the Ministry of Education recently announced on its website its intention to look into extending the school day, with the extra hours used to strengthen classes or do homework (Fakkar, 2014), both teachers and parents expressed concern. There is history of rewarding high performing teachers through incentive schemes with teachers eligible to receive BMWs and large monetary rewards (Arab Newsb, 2014b). Questions will surely arise around the viability of such incentive schemes along with distribution and selection of rewarded teachers. Monthly allowances for students (AL-Abdulkareem, 1993) along with incentive schemes for teachers, although seen as support mechanisms, are also likely to cause tensions in the implementation process. 


\section{Conclusion}

Maroun et al. (2008) report shows the percentage of gross domestic product invested in education from a cross section of countries including developed and developing countries such as the Gulf Cooperation Council Countries and Jordan. The report provides comparative data on employment, education development indexes and literacy rates all of which did not bode well for Gulf Cooperation Council Countries and, in particular, the Kingdom of Saudi Arabia. Countries such as Singapore and South Korea have been suggested as curriculum reform models that could be replicated or adapted due to their success and their rapid ascendance across education indexes because of improved student performance on international testing assessments such as The Program for International Student Assessment (PISA) and The Trends in International Mathematics and Science Study (TIMMSS).

As has been demonstrated in this section, there will be challenges and tensions associated with the curriculum reform process in the Kingdom of Saudi Arabia indicating, as Pinar et al. suggest, that curriculum "becomes the site on which the generations struggle to define themselves and the world" (p.847-848). It is envisaged that these tensions will not only be evident at the design and development level, but also at the classroom level as teachers' beliefs, capabilities and external factors such as time and school and community milieu influence teachers' actions in enacting curriculum in the Kingdom of Saudi Arabia.

\section{References}

AL-Abdulkareem, S. (1993). Educational development in Saudi Arabia (Historical project). Retrieved from www.faculty.ksu.edu.sa/

Al-Issa, A. (2011). Advancing English language teaching research in Gulf Cooperation Council States universities. The Modern Journal of Applied Linguistics, 3(2), 60-77.

Al-Issa, A. (2012). Re-conceptualizing English language teaching teacher education and development in the gulf cooperation council countries: addressing transformations and challenges. International Journal of Arts \& Sciences, 5(5), 537-599.

Allam, A. (2011, April 25). Saudi education reforms face resistance. Financial Times. Retrieved from http://www.ft.com/cms/s/0/07607fb0-6f5d-11e0-952c-00144feabdc0.html\#axzz3cjlkU7DY

Al-Talbi, A. (1993). al-farabi (259-339AH/872-950AD). Prospects: The Quarterly Review of Comparative Education (Paris, UNESCO: International Bureau of Education), XXIII(1/2), 353-372.

Arab News. (2014a, November 29). KSA universities not aligned with the jobs market. The Arab News. Retrieved from http://www.arabnews.com/featured/news/662676

Arab News. (2014b, October 15). Outstanding teachers to get BMWs. The Arab News. Retrieved from http://www.arabnews.com/featured/news/644631/

Bowen, G. A. (2009) Document Analysis as a Qualitative Research Method. Qualitative Research Journal, 9, 27-40. doi:10.3316/QRJ0902027.

Braun, V. and Clarke, V. (2006). Using thematic analysis in psychology. Qualitative Research in Psychology, 3(2), 77-101.

Cambridge International Examinations. (2015). Retrieved from http://www.cie.org.uk/news/news-details/view/indonesia-sees-steep-risein-schools-offering-cambridge-international-qualifications/

Eisner, E. (1985). Five basic orientations to the curriculum. In the educational imagination: on the design and evaluation of school programs. New York, NY: Macmillan.

Fakkar, J. (2014, December 18). Longer school hours proposal has parents worried. The Arab News. Retrieved from http://www.arabnews.com/featured/news/676081

Ferres, B. (2012, February 23). Great news for international teachers in Indonesia. International Schools Review. Retrieved from https://internationalschoolsreviewdiscuss.wordpress.com/2012/02/23/great-news-for-international-teachers-in-indonesia/

Fullan, M. \& Miles, M. (1992). Getting reform right: What works and what doesn't. Phi Delta Kappan, 73(10), 744-752.

Kabilan, M. K. (2007). English language teachers reflecting on reflections: A Malaysian experience. TESOL Quarterly, 41(4), $681-705$.

Khan, I. (2011a). Professionalization of ELT in Saudi Arabia. Interdisciplinary Journal of Contemporary Research in Business, 3(1), 885895.

Khan, I. (2011b). Professional development of English teachers: The Saudi Arabian context. Interdisciplinary Journal of Contemporary Research in Business, 3(2), 1583-1591.

Lee, K. (2012). Teaching intercultural English learning/teaching in world Englishes: Some classroom activities in South Korea. English Teaching, 11(4), 190.

Maroun, N., Samman, H., Moujaes, C. N., Abouchakra, R. (2008). How to Succeed at Education Reform The Case for Saudi Arabia and the Broader GCC Region. Booz \& Co. Retrieved from: http://www.ideationcenter.com/media/file/How_to_Succeed_at_Education_Reform_FINAL.pdf

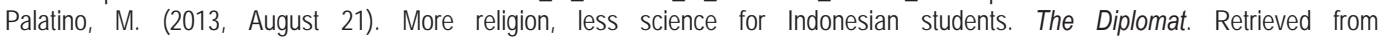
http://thediplomat.com/2013/08/more-religion-less-science-for-indonesian-students/

Pinar, W. F., Reynolds, W. M., Slattery, P., \& Taubman, P. M. (1995). Understanding curriculum: An introduction to the study of historical and contemporary curriculum discourses. New York, NY: Peter Lang. 
Richards, J. C. (2010). Competence and performance in language teaching. RELC Journal, 41(2), 101-122. doi:10.1177/0033688210372953

Selvaraj B. (2010). English language teaching (ELT) curriculum reforms in Malaysia. Voice of Academia, 5(1), 55-60.

White, N.J. (2004). British business in post-colonial Malaysia, 1957-70: Neo-colonialism or disengagement? London, United Kingdom: Routledge.

Wiseman, A. W., \& Al-bakr, F. (2013). The elusiveness of teacher quality: a comparative analysis of teacher certification and student achievement in Gulf Cooperation Council (GCC) Countries. Prospects: Quarterly Review of Comparative Education, DOI: 10.1007/s11125-013-9272-z. 